\title{
Measuring the benefits of screening for open neural tube defects
}

\author{
J B HENDERSON \\ From the Health Economics Research Unit, Department of Community Medicine, University of Aberdeen, \\ Aberdeen AB9 2ZD, UK
}

SUMMARY Evaluation of the costs and benefits of public sector programmes is necessary to plan the optimum uses for society's resources. Here the benefits of screening for open neural tube defects are examined, and the most appropriate methodological approach to their valuation is discussed in the context of the possible provision by the National Health Service of a routine prenatal screening programme. It is argued that, in measuring the benefits of screening, previous evaluations have adopted an approach that is rather unsatisfactory from the standpoint of economic methodology. An attempt is therefore made here to show the effect that adopting a more appropriate approach would have on the estimated value of the benefit of routine screening. The effect is found to be a substantial increase in its estimated value.

The recent Select Committee report on perinatal mortality ${ }^{1}$ included the recommendation that each regional health authority of the NHS should consider the establishment of a mass-screening programme for the prenatal detection and abortion of fetuses affected by open neural tube defect. Both this and the earlier report by the Working Group on Screening for Neural Tube Defects, ${ }^{2}$ chaired by Sir Douglas Black, have provoked discussion ${ }^{3}$ of the question of whether or not trying to prevent the birth of all affected infants, by terminating pregnancy, would benefit society as a whole. Cost-benefit analysis can usefully help attempts to reach an answer to this question. ${ }^{4}$

In all parts of the public sector, planning, aided by economic tools such as cost-benefit analysis, is necessary to produce efficient allocation of resources. ${ }^{5}$ Efficiency in the NHS means allocating resources so as to secure the maximum benefit, in terms of the relief of suffering caused by sickness and disability, that is attainable within the constraint of the NHS's limited budget. This implies that the benefit derived from each and every treatment or service offered should be at least as great as the opportunity cost of obtaining it (opportunity cost being the cost of foregoing the alternative benefits that could be derived from the resources consumed $\left.^{5}{ }^{6}\right)$. Hence under the cost-benefit criterion resources would be allocated to a screening programme and the programme extended to new client groups only if the benefits were equal to or greater than the opportunity cost.

Previously both a cost-benefit analysis of screening for spina bifida cystica ${ }^{7}$ and analysis of the cost-effectiveness to the public sector of screening for neural tube defects ${ }^{8}$ have suggested that the cost of a screening programme would be outweighed by the benefits that it would bring, except perhaps in areas of low incidence of neural tube defect. This paper extends the methodology of measuring the benefits of such screening programmes by comparing the costs and benefits of the cohort of handicapped individuals who would be born if there were no screening programme, with the costs and benefits of the cohort of "replacement" non-handicapped individuals who would probably be born if there were a screening programme. It is from the difference between these two that the cost of the screening programme itself has been subtracted to arrive at an estimate of its expected net benefit. This contrasts with the methodology of previous studies, which simply compared the costs of a handicapped individual with the costs of a non-handicapped individual (here termed the "excess cost" method) from which was subtracted the cost of the screening programme.

The methodology of the present study allows, firstly, for the fact that replacement can be less than $100 \%$; secondly, that individuals handicapped by open neural tube defect have a shorter 
life-expectancy than non-handicapped individuals, ${ }^{79}$ and, thirdly, that the cohort of replacement individuals will be born later than the handicapped cohort (estimated at one year after the abortion of an affected fetus) so their costs and benefits must be discounted by this extra year. ${ }^{5}$ Additionally, an estimate has been made of the intangible benefit to the parents of having a non-handicapped rather than a handicapped child. The estimate of the total benefit of a screening programme, so derived, is then compared, firstly, with that derived using the excess cost method and, secondly, with the estimated cost to the NHS of a screening programme contained in the report by Sir Douglas Black's working group. ${ }^{2}$

\section{Method}

Previous economic evaluations of screening for open neural tube defects have tended to exclude from the calculations the "human" or intangible costs and benefits, although there have been notable discussions $^{y}$ and studies ${ }^{10}$ of these aspects. The exclusion is understandable given the difficulty of valuing such intangibles but a cost-benefit analysis entails a much broader evaluation than a simple financial appraisal of the proposed course of action. ${ }^{11}$ Potentially important in the present context is the intangible psychological cost suffered by parents as a result of having a handicapped child compared with the lesser anguish and perhaps greater joy they might derive from a non-handicapped child, the opportunity for which replacement would be brought by a screening programme.

An attempt is also made here to take fuller account of the tangible effects of the replacement of terminated pregnancies. Other studies ${ }^{12}$ 13 have suggested that after abortion of an affected fetus and subsequent genetic counselling, a further pregnancy will probably be planned. (In the following analysis the simplifying assumption that replacement fetuses are not affected by neural tube defect will be made. It has been estimated ${ }^{14} 15$ that the average recurrence risk in Great Britain is in fact of the order of $5 \%$, although there are significant regional variations. $^{16-18}$ ) Thus as a direct result of the screening programme non-handicapped children will be born instead of children handicapped by neural tube defect. The cost of the resources consumed by these non-handicapped replacement individuals should therefore be deducted from any costs saved by preventing the birth of handicapped individuals. As noted elsewhere ${ }^{8}$ however, the cost savings brought by a screening programme do not include those due to preventing the birth of a second child affected by neural tube defect to mothers who have already had one such child, since these mothers would automatically be given prenatal diagnostic tests anyway.

The non-handicapped will have a much greater life-expectancy than will the handicapped, most of whom will probably die during infancy. ${ }^{9}$ Hence, even if replacement is $100 \%$, it is not legitimate simply to calculate the excess cost of resources consumed by one handicapped individual over and above the cost of equivalent (where appropriate) resources consumed by one non-handicapped individual. Rather, the comparison should be of the cost of resources consumed by the survivors from the cohort of handicapped born in the absence of a screening programme, with the cost of resources consumed by the survivors from the replacement cohort of non-handicapped born in the presence of a screening programme.

Obviously, there must be a delay of at least nine months between the abortion of an affected fetus and the birth of a replacement infant. This delay is important because costs and benefits that occur in later time periods should be multiplied by a discount factor to obtain their present values. (Discounting reflects the fact, which is shown by the necessity to pay interest in order to induce people to lend money and thereby postpone consumption, that future benefits, whether financial or non-financial, are generally regarded as being worth less than benefits to be gained in the present.)

In the light of the points made above, the cost savings and benefits attributable to the avoidance of the birth of a cohort of infants handicapped by open spina bifida have been calculated. Different assumptions have been used for the rate of replacement conceptions, assumed to follow both the abortion of an affected fetus and the death of a handicapped child in infancy: no replacement, 50\% replacement, and $100 \%$ replacement. While only a little evidence ${ }^{12}$ is available concerning the duration of the delay of replacement it is likely to be less than the two year average interval between live-born siblings and so an estimate of one year has been used. The proportions surviving each year from the cohorts born in the absence and presence of a screening programme have been calculated from published mortality data, ${ }^{79}{ }^{19}$ and their expected survival experience is summarised in table 1 .

The difference in net cost of the two cohorts is the main benefit of screening that follows from a true-positive test result, but there are other costs and benefits associated with the other possible outcomes of the screening test (table 2). While the main purpose of screening is to detect open spina bifida, anencephaly may also be detected by the screening tests. Preventing the birth of anencephalic infants is desirable since it will reduce parental distress and 
Table 1 Average survival experience of 100 male and 100 female births and expected survival experience of 100 individuals handicapped by open spina bifida

\begin{tabular}{llll}
\hline $\begin{array}{l}\text { No } \\
\text { surviving } \\
\text { at age }\end{array}$ & $\begin{array}{l}\text { From 100 } \\
\text { male births }\end{array}$ & $\begin{array}{l}\text { From 100 } \\
\text { female births }\end{array}$ & $\begin{array}{l}\text { From 100 } \\
\text { open spina } \\
\text { bifida births }\end{array}$ \\
\hline$<1$ & 98.4 & 98.8 & 86.1 \\
1 & 98.3 & 98.7 & 35.9 \\
5 & 98.1 & 98.5 & 29.4 \\
10 & 98.0 & 98.4 & 29.0 \\
20 & 97.3 & 98.1 & 26.4 \\
30 & 96.4 & 97.6 & 21.4 \\
45 & 93.3 & 95.5 & 10.8 \\
60 & 78.0 & 86.5 & 5.8 \\
75 & 38.6 & 59.5 & 2.9 \\
90 & 2.7 & 8.7 & 0.2 \\
\hline
\end{tabular}

Table 2 Classification of benefits and costs by test result

\begin{tabular}{lll}
\hline & The state of nature & \\
\cline { 2 - 3 } Test result & Negative & Positive \\
\hline Negative & $\begin{array}{l}\text { Benefit of reassurance } \\
\text { to parents of unaffected } \\
\text { children }\end{array}$ & $\begin{array}{l}\text { Cost of distress to } \\
\text { parents incorrectly reassured }\end{array}$ \\
$\begin{array}{l}\text { Cost of distress to } \\
\text { parents of unaffected } \\
\text { children, risk of } \\
\text { accidental fetal loss or } \\
\text { damage caused by } \\
\text { amniocentesis and } \\
\text { inappropriate abortion }\end{array}$ & $\begin{array}{l}\text { Cost savings and benefits } \\
\text { from avoiding the birth of } \\
\text { the cohort of individuals } \\
\text { handicapped by open spina } \\
\text { bifida and from detecting } \\
\text { anencephaly }\end{array}$ \\
\hline
\end{tabular}

also produce some small financial benefit to the NHS. The detection of anencephaly is therefore included under the true-positive outcomes. A false-positive test result, however, may include some risk of fetal damage or loss ${ }^{3}$ and distress to the parents ${ }^{10}$ owing to amniocentesis. There may also be an increase in distress to parents caused by a false-negative test result but, doubtless, much reassurance to most parents from a true-negative test result. It has not been possible to put monetary values on these other costs and benefits. Hence, as noted elsewhere, ${ }^{39}$ conclusions about the overall benefit of a screening programme that are based on a comparison of the difference in net cost of the two cohorts with the cost of screening are only valid if these other costs are outweighed by these other benefits. Fortunately, this seems likely.

Fuller details of the data used, their sources, and a breakdown of the costs are available ${ }^{20}$ but they are summarised in table 3 and described briefly below. Ideally all costs and benefits should be included whoever bears or receives them, but it is impossible to know the cost to a fetus of being aborted or the benefit to a potential replacement fetus of being conceived. Moreover the issues here have much more to do with ethics than economics. Therefore the sign given to the costs and benefits in table 3 depends only on whether the rest of society receives a benefit from the screening programme. The value of goods and services in categories $(a),(b),(d)$, and $(e)$ of table 3 has been obtained from usage data in previous studies of the handicapped ${ }^{82122}$ and from official surveys. ${ }^{23-28}$ Goods and services provided publicly, other than those specifically mentioned in category (b), have been assumed either to cost a negligible amount per consumer or to be "public goods" that can only be consumed collectively-for instance, defence-which means that the "marginal" or incremental cost of their consumption by either cohort is zero.

Any unmarketed output produced has been assumed to be completely consumed by the producer implying that the benefit of the output and the cost of the consumption to the rest of society is zero and therefore these benefits and costs (categories $(c)$ and $(f)$ ) have been omitted from the calculations. A case where this assumption is obviously incorrect is that of household services produced by women. For most women personal consumption of unmarketed household services will be less than the output they produce. It has been implicitly assumed, however, that the remaining output is consumed by husbands within the same cohort to ensure that when the costs of men and women are combined the output and consumption of unmarketed goods and services sum to zero and can be excluded from the analysis.

As a minimum estimate of the intangible benefit, net of intangible cost, that children bring to their parents, the financial costs to parents of having a non-handicapped child have been calculated on the principle that if parents are freely prepared to pay these costs then they must receive at least as much net psychological benefit. Various reductions of this value have then been used to estimate the lesser psychological benefit of having a handicapped child. ${ }^{29}$ As a minimum estimate, a net value of zero has been used, implying that the psychological costs and benefits of having a handicapped child are equal. As a middle value, an estimate of $50 \%$ of the value imputed to the non-handicapped has been used. As a maximum estimate, a net value equal to that imputed to the non-handicapped has been used, implying that, in terms of psychological costs and benefits, parents are indifferent between having a handicapped and a non-handicapped child. Other values in categories $(g)$ and $(h)$ have not been calculated.

\section{Results}

One would expect the net cost to society of any given number of individuals handicapped by open spina bifida to be greater than the net cost to society of an equal number of non-handicapped individuals of the same age and indeed the results of the present study 
Table 3 Classification of benefits and costs of cohort handicapped by open spina bifida and of "replacement" cohort

\begin{tabular}{|c|c|c|}
\hline $\begin{array}{l}\text { Description } \\
\text { (Figures are } f \text { thousands at November } 1979 \text { prices) }\end{array}$ & $\begin{array}{l}\text { Cost savings and } \\
\text { benefits from } \\
\text { avoiding birth } \\
\text { of a cohort of } \\
100 \text { individuals } \\
\text { handicapped by } \\
\text { open spina bifida* }\end{array}$ & $\begin{array}{l}\text { Benefits arising } \\
\text { from birth of } \\
\text { a replacement } \\
\text { cohort of } 100 \\
\text { non-handicapped } \\
\text { individuals" }\end{array}$ \\
\hline $\begin{array}{l}\text { Tangible } \\
\text { (a) Consumption of goods and services marketed privately } \\
\text { (b) Consumption of goods and services provided publicly: } \\
\text { Health services including any special treatment } \\
\text { Education including any special education } \\
\text { Permanent care } \\
\text { (c) Consumption of unmarketed goods and services: } \\
\text { Produced by parents during childhood } \\
\text { Produced by spouse during adult life } \\
\text { (d) Lost maternal marketed output during childhood } \\
\text { (e) Own marketed output during working life } \\
\text { (f) Own unmarketed output } \\
\text { Intangible } \\
\text { (g) Worry, distress, and other psychological costs to family and friends } \\
\text { (h) Joy, happiness, and other psychological benefits to family and friends }\end{array}$ & $\begin{array}{l}+512 \\
+120 \\
+248 \\
+109\end{array}$ & $\begin{array}{l}-1452 \\
-151 \\
-378\end{array}$ \\
\hline
\end{tabular}

*A plus sign indicates a benefit to the rest of society, such as the availability of greater amounts for consumption or a reduction in distress and so forth and a minus sign indicates a cost to the rest of society. The costs and benefits have been adjusted to reflect the different survival experience of the two cohorts. All future costs and benefits have been converted to their present values using a discount rate of $7 \%$.

+Value depends on assumption made-see text.

confirm this. ${ }^{20}$ As explained earlier, however, simply taking the excess cost of the former over the latter is not a wholly appropriate method of measuring the benefit of a screening programme. When allowance is made for different rates of replacement, the delay of replacement, and the different survival experience of

Table 4 Estimated tangible benefit

Benefit from avoiding birth of 100 individuals handicapped by open spina bifida assuming:

\begin{tabular}{lllll} 
& $\begin{array}{l}\text { Zero } \\
\text { replacement }\end{array}$ & $\begin{array}{l}50 \% \\
\text { replacement }\end{array}$ & $\begin{array}{l}100 \% \\
\text { replacement }\end{array}$ & $\begin{array}{l}\text { Excess } \\
\text { cost } \\
\text { method }\end{array}$ \\
\hline Discounted at 4\% & 1988 & 1734 & 1481 & 1215 \\
Discounted at 7\% & 1619 & 1289 & 959 & 827 \\
Discounted at 10\% & 1376 & 1045 & 713 & 619 \\
\hline
\end{tabular}

$£$ thousands at November 1979 prices.

Table 5 Estimated tangible benefit plus estimated intangible benefit

Benefit including avoidance of estimated psychological cost to parents, assuming $100 \%$ replacement

\begin{tabular}{lrrrl} 
& \multicolumn{1}{c}{$(1)$} & (2) & (3) & (4) \\
\hline Discounted at $4 \%$ & 1481 & 1468 & 1696 & 1925 \\
Discounted at 7\% & 959 & 937 & 1141 & 1345 \\
Discounted at $10 \%$ & 713 & 684 & 869 & 1054
\end{tabular}

(1) No psychological benefit to parents of non-handicapped children and no psychological benefit to parents of children handicapped by open spina bifida.

(2)-(4) Including estimated psychological benefit to parents of non-handicapped children and same psychological benefit to parents of children handicapped by open spina bifida (adjusted for numbers surviving) and

(2) Not reduced,

(3) Reduced by $50 \%$,

(4) Reduced by $100 \%$

$£$ thousands at November 1979 prices. the two cohorts, different results emerge (table 4). Table 5 shows the effect of avoiding the estimated psychological cost suffered by parents. The figure illustrates the main findings.

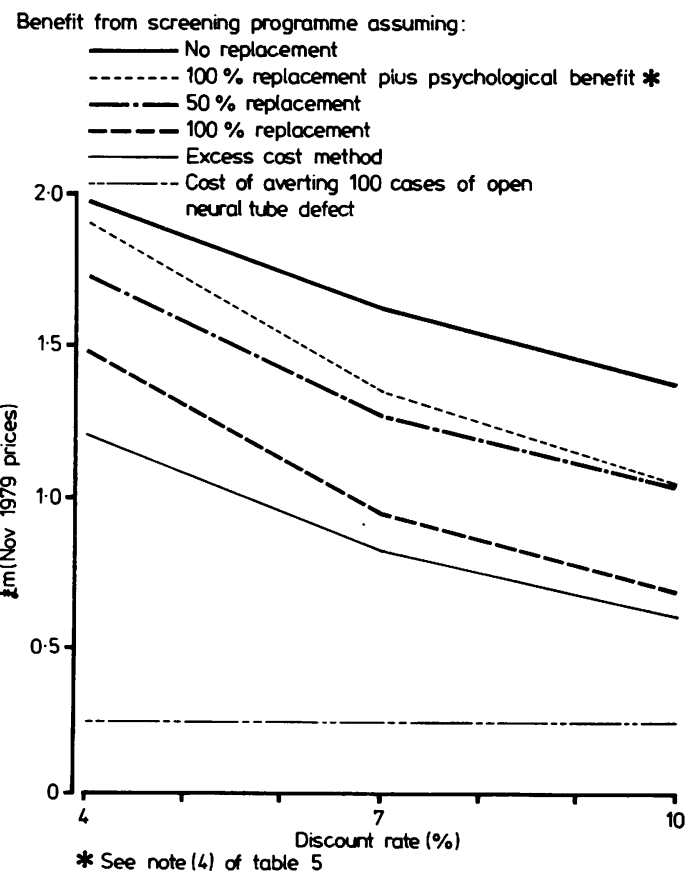

Estimated benefit under different assumptions compared with estimated cost of a screening programme. 
The "correct" rate at which to discount future costs and benefits is still a matter of debate, ${ }^{6}$ so a range of rates, including the public sector test discount rate of $7 \%$ recommended by the Treasury, has been used to show the sensitivity of the findings to different rates. The results suggest that the net tangible benefit (at November 1979 prices) from avoiding the birth of a nominal cohort of 100 individuals handicapped by open spina bifida ranges with no replacement from about $£ 2 \mathrm{~m}$ at a $4 \%$ discount rate to about $£ 1.4 \mathrm{~m}$ at a $10 \%$ discount rate; with $50 \%$ replacement from about $£ 1.7 \mathrm{~m}$ to about $£ 1 \mathrm{~m}$; with complete replacement from about $£ 1.5 \mathrm{~m}$ to about $£ 0.7 \mathrm{~m}$.

These results are compared in table 4 with those obtained using the excess cost method (which assumes complete and immediate replacement by unaffected fetuses). The excess cost method underestimates the benefit by between $£ 0.3 \mathrm{~m}(4 \%$ discount rate) and $£ 0.1 \mathrm{~m}$ ( $10 \%$ discount rate) or by between $18 \%$ and $13 \%$. The difference is clearly much greater if replacement is less than $100 \%$.

Table 5 shows the contrast to be more pronounced when an estimate of the psychological cost suffered by parents is included. If, for example, replacement is complete and it is assumed that the psychological costs and benefits to parents of having a handicapped child are equal, the minimum estimated benefit now ranges from about $£ 1.9 \mathrm{~m}$ ( $4 \%$ discount rate) to about $£ 1 \cdot 1 \mathrm{~m}$ ( $10 \%$ discount rate). The amount by which the excess cost method underestimates the benefit is increased to between $£ 0.7 \mathrm{~m}$ and $£ 0.4 \mathrm{~m}$ or by between $37 \%$ and $41 \%$.

To place the results in the context of a national screening programme for open neural tube defects the cost of detecting 100 cases of open neural tube defects is also shown in the figure. The cost used is the revenue cost taken from the report by Sir Douglas Black's working group ${ }^{2}$ and revalued to November 1979 prices. The results reinforce the conclusions of other studies ${ }^{78}$ that the tangible benefits of screening probably outweigh the tangible costs by a substantial amount, irrespective of the discount rate used, and the same may well be true of the intangibles.

\section{Discussion}

The results show that an appropriate method of calculating costs and benefits is to compare the non-implementation of a programme with the situation that would obtain if it were implemented. Wherever possible, too, the analysis should include the evaluation of an alternative policy, such as, in the present context, dietary counselling, if it proves to be feasible. ${ }^{30} 31$ Calculating costs and benefits also entails more than adding up money outlays and receipts: the intangible and other aspects of a programme must not be ignored. Even such crude estimates of intangible costs and benefits as those presented here can make a significant difference to the results of a cost-benefit analysis.

The method used here would also be appropriate for measuring the benefits of other screening programmes for the prenatal detection of fetal malformations, where detection is followed by termination of pregnancy and a replacement pregnancy is likely, as with the routine provision of prenatal diagnosis of Down's syndrome. ${ }^{32}$ Although these and similar ${ }^{33}$ evaluations may be criticised on the methodological grounds discussed here, they nevertheless represent an important contribution to the rational planning of resource use in health services. Such planning is indispensable if the NHS, from its limited budget, is to attempt to maximise the benefits that it produces for society. ${ }^{34}$

I am very grateful for the helpful advice of Messrs Andrew Burchell, Robert Weeden, and Gordon Harris of the Economic Advisers' Office of the Department of Health and Social Security, where an earlier version of this paper was written in fulfilment of the requirements for the degree of Master of Science in economics at the University of York, with financial support from the Social Science Research Council. I am also grateful for comments to Messrs Gavin Mooney and David Cohen of the Health Economics Research Unit, University of Aberdeen, and an anonymous reviewer. The views expressed are, of course, mine and not necessarily those of anyone mentioned above.

\section{References}

${ }^{1}$ House of Commons Social Services Committee. Session 1979-80, second report: perinatal and neonatal mortality. London: HMSO, 1980.

${ }^{2}$ Working Group on Screening for Neural Tube Defects. Report. London: DHSS, 1979.

${ }^{3}$ Harris R. Maternal serum alphafetoprotein in pregnancy and the prevention of birth defect. $\mathrm{Br} \mathrm{Med} J$ 1980; 280: 1199-202.

${ }^{4}$ Williams A. The cost-benefit approach. Br Med Bull 1974; 30: 252-6.

${ }^{5}$ Williams A, Anderson R. Efficiency in the social services. Oxford: Basil Blackwell, 1975.

${ }^{6}$ Drummond MF. Principles of economic appraisal in health care. Oxford: Oxford University Press, 1980.

${ }^{7}$ Hagard S, Carter F, Milne RG. Screening for spina bifida cystica, a cost-benefit analysis. Br J Prev Soc Med 1976; 30: $40-53$.

${ }^{8}$ Glass N, Cove AR. Cost-effectiveness of screening for neural tube defects. In: Scrimgeour JB, ed. Towards the prevention of fetal malformations. Edinburgh: Edinburgh University Press, 1978: 217-23. 
${ }^{y}$ Chamberlain J. Human benefits and costs of a national screening programme for neural-tube defects. Lancet 1978; ii: 1293-6.

${ }^{10}$ Farrant W. Stress after amniocentesis for high serum alpha-fetoprotein concentration. $\mathrm{Br} \mathrm{Med} J$ 1980; 281: 452.

${ }^{11}$ Sugden R, Williams A. The principles of practical cost-benefit analysis. Oxford: Oxford University Press, 1978.

${ }^{12}$ Morris J, Laurence KM. The effectiveness of genetic counselling for neural-tube malformations. Dev Med Child Neurol 1976; 18, suppl 37: 157-63.

${ }^{13}$ Modell B, Ward RHT, Fairweather DVI. Effect of introducing antenatal diagnosis on reproductive behaviour of families at risk for thalassaemia major. $\mathrm{Br}$ Med J 1980; 280: 1347-50.

${ }^{14}$ Blyth H, Carter C. A guide to genetic prognosis in paediatrics. Dev Med Child Neurol 1969; 11, suppl 18, (whole booklet).

${ }^{15}$ Laurence KM. Fetal malformations and abnormalities. Lancet 1974; ii: 939-41.

${ }^{16}$ Carter CO, David PA, Laurence KM. A family study of major central nervous system malformations in South Wales. J Med Genet 1968; 5: 81-106.

${ }^{17}$ Carter CO, Evans $\mathrm{K}$. Spina bifida and anencephalus in Greater London. J Med Genet 1973; 10: 209-34.

18 Richards IDG, McIntosh HT, Sweenie S. A genetic study of anencephaly and spina bifida in Glasgow. Dev Med Child Neurol 1972; 14: 626-39.

${ }^{19}$ Central Statistical Office. Annual abstract of statistics 1979. London: HMSO, 1979.

${ }^{20}$ Henderson JB. An economic evaluation of the benefits of screening for open spina bifida. Aberdeen: University of Aberdeen Health Economics Research Unit, 1981. (Discussion paper 01/81.)

${ }^{21}$ Bradshaw J. The financial problems of families with handicapped children and an evaluation of the attendance allowance. York: University of York, Department of Social Administration and Social Work, Social Policy Research Unit, 1974. (Working Paper FF 19/11. 74 SB.)
${ }^{22}$ Evans K, Hickman V, Carter CO. Handicap and social status of adults with spina bifida cystica. Br J Prev Soc Med 1974; 28: 85-92.

${ }^{23}$ Office of Population Censuses and Surveys. General household survey 1978. London: HMSO, 1980.

${ }^{24}$ Department of Employment. Family expenditure survey 1976. London: HMSO, 1977.

${ }^{25}$ Department of Employment. New earnings survey 1979. London: HMSO, 1979.

${ }^{28}$ Department of Health and Social Security. Hospital in-patient enquiry 1975. London: HMSO, 1978.

${ }^{27}$ Office of Population Censuses and Surveys. Second national study of morbidity statistics from general practice 1970/71. London: HMSO, 1974.

${ }^{28}$ Department of Health and Social Security. Health service costing returns 1977. London: HMSO, 1979.

${ }^{29}$ Walker JH, Thomas M, Russell IT. Spina bifida and the parents. Dev Med Child Neurol 1971; 13: 462-76.

${ }^{30}$ Smithels RW, Sheppard S, Schorah CJ, et al. Possible prevention of neural-tube defects by periconceptional vitamin supplementation. Lancet 1980; i: 339-40.

${ }^{31}$ Laurence KM, James N, Miller M, Campbell H. Increased risk of recurrence of pregnancies complicated by fetal neural tube defects in mothers receiving poor diets and possible benefit of dietary counselling. $\mathrm{Br} \mathrm{Med} \mathrm{J} \mathrm{1980;}$ 281: $1592-4$.

${ }^{32}$ Hagard S, Carter FA. Preventing the birth of infants with Down's syndrome: a cost-benefit analysis. $\mathrm{Br} \mathrm{Med} J$ 1976; i: 753-6.

${ }^{33}$ Layde PM, von Allmen SD, Oakley GP. Maternal serum alpha-fetoprotein screening: a cost-benefit analysis. Am J Public Health 1979; 69: 566-73.

${ }^{34}$ Mooney GH. Cost-benefit analysis and medical ethics. $J$ Med Ethics 1980; 6: 177-9. 